\title{
Morphological Alterations of the Fission Yeast Schizosaccharomyces pombe in the Presence of Aculeacin A: Spherical Wall Formation
}

\author{
By MACHIKO MIYATA, ${ }^{*} \dagger$ TOSHIO KANBE ${ }^{2}$ AND KENJI TANAKA ${ }^{2}$ \\ ${ }^{1}$ Gifu Pharmaceutical University, 6-1, Mitahora-higashi 5 chome, Gifu 502, Japan \\ ${ }^{2}$ Laboratory of Medical Mycology, Research Institute for Disease Mechanism and Control, \\ Nagoya University School of Medicine, Tsurumai 65, Showa-ku, Nagoya 466, Japan
}

(Received 3 July 1984 ; revised 26 October 1984)

\begin{abstract}
The fission yeast Schizosaccharomyces pombe, grown in the presence of aculeacin A (Acu), an antifungal antibiotic, forms spherical rather than cylindrical walls. This aberrant morphogenesis was studied in the presence of Acu at $1 \mu \mathrm{g} \mathrm{m}^{-1}$ under conditions in which over $90 \%$ of the cells continued to grow but with altered morphology. Microscopic observations and chemical analyses revealed that the spherical walls had a looser structure than the cylindrical wall and that their syntheses of alkali-insoluble glucan and mannan were reduced whereas the synthesis of alkali-soluble glucan was enhanced. Spherical walls of glutaraldehyde-fixed cells were hardly digested by Zymolyase 60000 [a ( $1 \rightarrow 3)$ - $\beta$-glucanase] but were digested by Novozym 234 [a ( $1 \rightarrow 3)$ $\alpha$-glucanase]. From these results the components and morphology of the spherical walls are discussed in comparison with the cylindrical walls.
\end{abstract}

\section{INTRODUCTION}

Although the mechanism of biosynthesis of yeast cell wall polymers is quite well understood (Nečas \& Svoboda, 1980; Cabib \& Roberts, 1982), practically nothing is known as to how the molecular architecture of individual polysaccharides is related to cell shape. The morphology of the yeast wall may depend on certain mutual interactions of its component polysaccharides. The use of suitable selective inhibitors of polysaccharide synthesis is one approach to the study of cell wall synthesis and its control mechanisms. Alterations in wall composition due to the action of these inhibitors are often accompanied by changes in the morphology of the cell (BartnickiGarcia \& McMurrough, 1971). Aculeacin A (Acu) is an antifungal antibiotic produced by Aspergillus aculeatus, discovered in the research laboratories of Toyo Jozo Co., Japan, which inhibits the $\beta$-glucan synthesis of yeast cell walls (Mizoguchi et al., 1977; Yamaguchi et al., 1982), resulting in the lysis of cells. Earlier studies (Miyata et al., 1980) showed that Acu caused lysis of the growing fission yeast Schizosaccharomyces pombe at the end of the cell and in the cellplate region, the regions of active wall synthesis, and that Acu-resistant cells survived and exhibited morphological alterations of spherical growth at one or both ends of the cell as 'roundbottomed flask' (RBF) or dumb-bell shapes.

The present study is concerned with the nature of the morphological changes resulting from Acu treatment of the fission yeast $S$. pombe. The differences in cell wall constituents and fine structure between spherical and cylindrical walls of $S$. pombe were investigated.

\footnotetext{
† Present address: c/o Dr B. F. Johnson, Division of Biological Sciences, National Research Council of Canada, Ottawa, Ontario, Canada KIA 0R6.

Abbreviations: Acu, aculeacin A; RBF, 'round-bottomed flask' shape.
} 


\section{METHODS}

Yeast strains. Schizosaccharomyces pombe IFO 0365 was obtained from the Institute for Fermentation Osaka, Osaka, Japan. The temperature-sensitive mutant $c d c$ 10-121 h- of a wild-type strain $972 \mathrm{~h}^{-}$was kindly provided by Professor U. Leupold, Bern University, Switzerland. The mutant is unable to synthesize DNA when transferred from $25^{\circ} \mathrm{C}$ to $35^{\circ} \mathrm{C}$ and so grows only in cell length with a single nucleus (Nurse et al., 1976).

Media and culture conditions. All experiments were done with minimal medium (EMM 2; Mitchison, 1970). Cultures were grown in Erlenmeyer flasks with a capacity of three times the volume of the medium, with shaking in a water bath. Cells were precultured twice after inoculation from stock cultures either for $24 \mathrm{~h}$ at $32{ }^{\circ} \mathrm{C}$ for strain IFO 0365 or for $30 \mathrm{~h}$ at $25^{\circ} \mathrm{C}$ for strain $c d c 10-121 \mathrm{~h}^{-}$. They were inoculated into the fresh medium at a density of 5 $\times 10^{5}$ cells ml $^{-1}$ and $2.5 \times 10^{6}$ cells ml ${ }^{-1}$, respectively, and further cultured for $16 \mathrm{~h}$ at the same temperatures. All experiments were done with the $16 \mathrm{~h}$-grown cells.

Determinations of cell number and percentage lysis. Cell number and percentage lysis were determined as described previously (Miyata et al., 1980).

Electron microscopy. Cells were observed with scanning and transmission electron microscopes. The yeasts were prepared for scanning electron microscopy as follows. Washed cells were fixed in $2.5 \%(\mathrm{v} / \mathrm{v})$ glutaraldehyde solution in potassium phosphate buffer $(0.15 \mathrm{M}, \mathrm{pH} 6.8)$ at $4{ }^{\circ} \mathrm{C}$ for $2 \mathrm{~h}$ and postfixed in $1 \% \mathrm{OsO}_{4}$ in the same buffer at room temperature for $2 \mathrm{~h}$. Fixed cells were dehydrated through an acetone series and suspended in isoamyl acetate. The specimens were dried by the critical point drying method and coated with gold vapour. Observations were made using an Akashi MSM-9 scanning electron microscope.

Preparation for transmission electron microscopy followed the method described by Hirata \& Tanaka (1982). After fixing in $3 \%$ glutaraldehyde in $0.1 \mathrm{M}$-potassium phosphate buffer, $\mathrm{pH} 7.0$, for $2 \mathrm{~h}$, the cells were washed several times in the buffer and postfixed in $2 \% \mathrm{KMnO}_{4}$ for 30 to $40 \mathrm{~min}$. After washing in distilled water, the cells were stained in $0.5 \%$ uranyl acetate for $2 \mathrm{~h}$. After dehydration through an acetone series, the cells were embedded in Spurr's resin (Spurr, 1969). Sections were obtained using a Diatome diamond knife on a Reichert Ultracut Om U4 and mounted on Formvar-coated grids. They were stained with lead citrate and viewed in a JEOL 100CX or Hitachi H-800 electron microscope at 80 or $100 \mathrm{kV}$.

Enzymic digestions of cell walls were done between the fixation of cells in glutaraldehyde and the postfixation in $\mathrm{KMnO}_{4}$. The fixed cells were suspended at a density of $2 \times 10^{7}$ cells $\mathrm{ml}^{-1}$ in solutions containing $1 \mathrm{mg}$ enzyme dissolved in $5 \mathrm{ml}$ buffer. The incubations were performed with mild shaking under the following conditions: (1) Novozym 234 (Novo Enzyme Produces, Windsor, UK) in a buffer of $0.01 \mathrm{M}$-citrate/phosphate, pH 5.8 at $30^{\circ} \mathrm{C}$ for $10 \mathrm{~min}$; (2) Zymolyase 60000 (Kirin Brewery Co., Takasaki, Japan) in $0 \cdot 1 \mathrm{M}$-potassium-phosphate buffer, pH 7.0 at $30{ }^{\circ} \mathrm{C}$ for $90 \mathrm{~min}$. After treatment with Novozym 234, in order to avoid the destruction and swelling of the cytoplasmic structure, the postfixative $\mathrm{KMnO}_{4}$ contained $0.6 \mathrm{M}-\mathrm{KCl}$ and the final washing solution was $0.6 \mathrm{M}$ $\mathrm{KCl}$.

Shadowed preparations were done as follows: a suspension of walls in water was sprayed and dried on carboncoated copper grids (200 mesh) which were shadowed at an angle of $25^{\circ}$ with platinum-palladium.

Carbohydrate analysis. Cell wall polysaccharides were fractionated by a modification of the method of Northcote \& Horne (1952). The whole cells were digested with $0.8 \mathrm{M}-\mathrm{NaOH}$ at $100^{\circ} \mathrm{C}$ for $1 \mathrm{~h}$. The precipitate obtained by centrifugation was washed twice with the same alkaline solution and once with distilled water. The combined supernatants were used as the 'alkali-soluble fraction'. The precipitate was further extracted twice with $0.5 \mathrm{M}$-acetic acid at $90^{\circ} \mathrm{C}$ for $3 \mathrm{~h}$ and at room temperature for $18 \mathrm{~h}$. The precipitate obtained was used as the 'alkali-insoluble fraction'.

Total carbohydrate was determined by the anthrone method described by Herbert et al. (1971). The glucan and mannan contents were determined by using a modification of the $\mathrm{H}_{2} \mathrm{SO}_{4}$ /carbazole differential extinction method described by McMurrough \& Rose (1967).

The monosaccharide composition was determined by gas-liquid chromatography after conversion of acid hydrolysates into the corresponding alditol acetates (Slonecker, 1972). These were then analysed on a Shimazu gas chromatograph GC-4CM through a glass column $(0 \cdot 3 \times 150 \mathrm{~cm})$ packed with $3 \%$ ECNSS-M Gaschrome $Q(100$ to 120 mesh) at $175^{\circ} \mathrm{C}$ at a flow rate of $50 \mathrm{ml} \mathrm{N}_{2} \mathrm{~min}^{-1}$.

Chemicals. Glutaraldehyde, uranyl acetate and Spurr resin were purchased from Nisshin KK (Tokyo, Japan), Merck and Polysciences Inc., (Warrington, USA), respectively. All other chemicals used were of analytical grade from commercial sources.

\section{RESULTS}

Acu-resistant survivors of $S$. pombe strain IFO 0365 exhibited morphological alterations of either a 'round-bottomed flask' (RBF) or dumb-bell shape (Miyata et al., 1980). Preliminary experiments established how these survivors might be used for studies on cellular morphogenesis. 


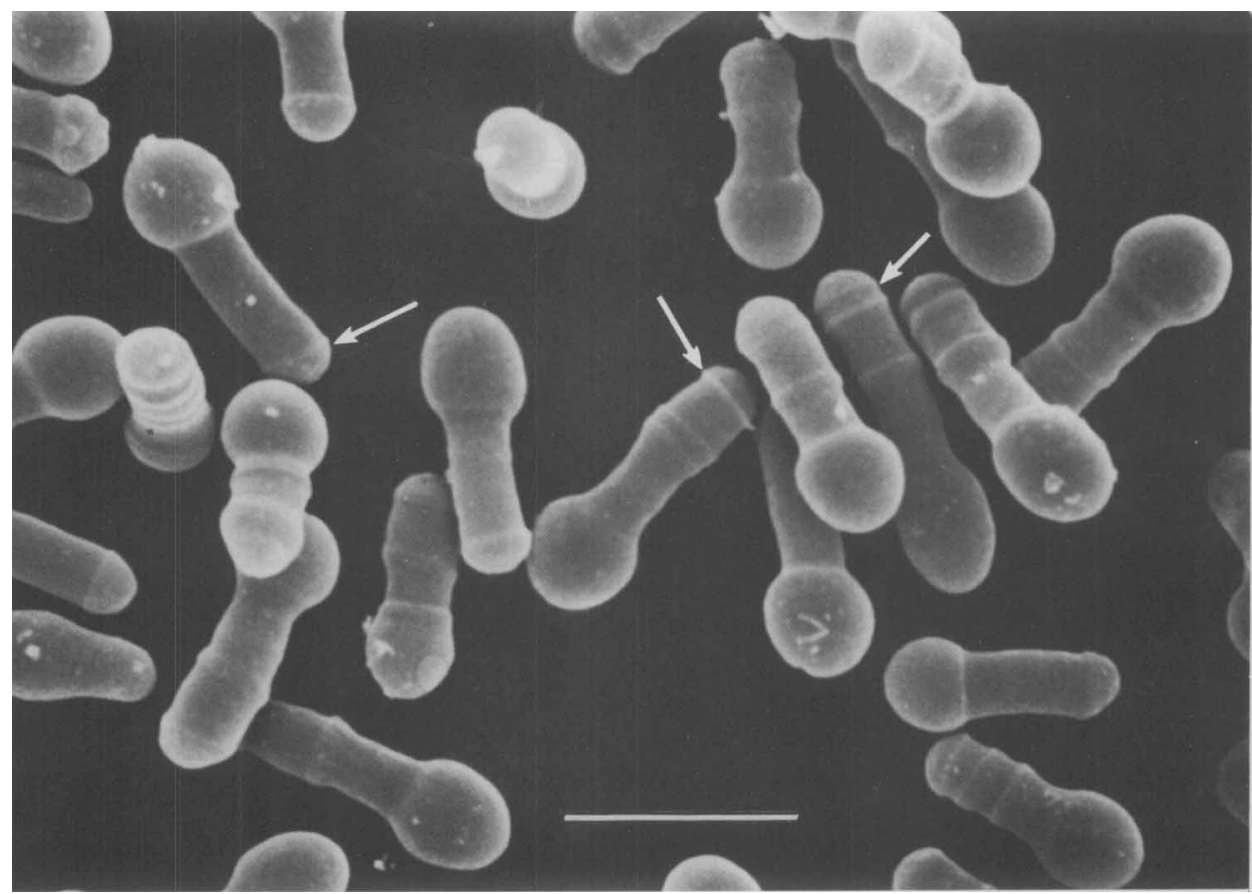

Fig. 1. Scanning electron micrograph of RBF-like cells from a 3 h culture of the 'cell elongation system' in the presence of Acu, in which over $90 \%$ of strain IFO 0365 cells have survived and continued to grow. Arrows indicate the positions of division scars at the end of the cylindrical poles; bar, $10 \mu \mathrm{m}$.

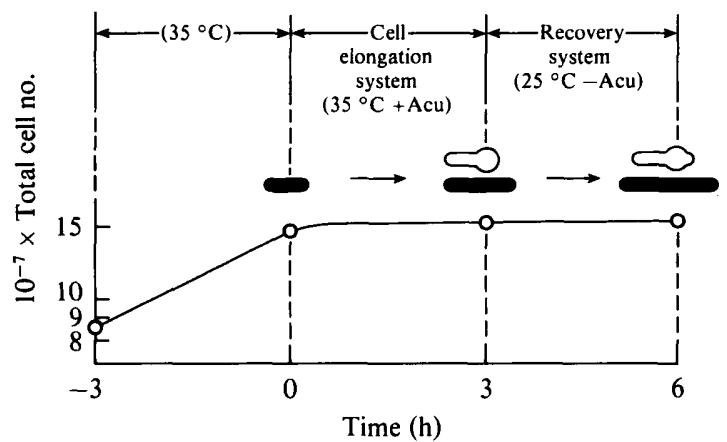

Fig. 2. Growth of $S$. pombe cells in the presence or absence of Acu in the 'cell elongation system' and the 'recovery system'. Open cells are those in the presence of Acu; filled cells are controls. Acu was added at time zero.

In order to characterize the changes induced by Acu morphologically and biochemically, we used the 'cell elongation system' (Miyata \& Miyata, 1978; Miyata et al., 1980) in which growth in cell length continued exponentially after the arrest of cell division. By using this system, the experimental conditions in which nearly $100 \%$ of the organisms did not lyse but grew spherically in the presence of Acu were examined. The conditions established were as follows: $16 \mathrm{~h}$-grown cells were transferred into fresh medium containing $16 \mathrm{mM}$-hydroxyurea at a cell density of $2 \times 10^{7}$ cells ml-1 and incubated for $3 \mathrm{~h}$ at $32^{\circ} \mathrm{C}$. At this time, when the cell density was about $4 \times 10^{7}$ cells $\mathrm{ml}^{-1}$, Acu was added to a final concentration of $2 \mu \mathrm{g} \mathrm{ml}^{-1}$. After further incubation for $3 \mathrm{~h}$, approximately $90 \%$ of the yeast survived and all cells were RBF-like (Fig. 1). If $0.8 \mathrm{M}$-mannitol was added, the survival was more than $90 \%$ (Miyata et al., 1980). 
All RBF-like cells had division scars at the pole of their cylindrical region but no scars at the spherical region (Fig. 1). This observation suggests that the older wall remained as a cylindrical end of the cell and that the newly synthesized material deposited in the presence of Acu formed a spherical wall.

Secondly, the mutant $c d c 10-121 \mathrm{~h}^{-}$was used to create an experimental condition similar to that of strain IFO 0365. This strain ceased its cell division at about $3 \mathrm{~h}$ after the shift to $35^{\circ} \mathrm{C}$ and increased the cell length exponentially on prolonged incubation at the same temperature (Fig. 2; see control cells). Thus, the 'cell elongation system' could be simply and economically set up, not by adding hydroxyurea but by changing the temperature. Three hours after the shift to $35^{\circ} \mathrm{C}$, Acu was added and the experiment was started at time zero (Figs 2 and 5). Under these conditions, more than $90 \%$ of cells lysed when the cell density was $1.0 \times 10^{6}$ cells ml $^{-1}$ and when the rate of cell elongation was too fast, but cells neither lysed nor altered their morphology when the cell density was $5.0 \times 10^{7}$ cells $\mathrm{ml}^{-1}$ and when the rate of growth was too slow. The conditions in which $90 \%$ of the Acu-treated yeasts grew in a spherical form were established as follows. The $16 \mathrm{~h}$-grown cells were inoculated into fresh medium at a density of $8.5 \times 10^{6}$ cells $\mathrm{ml}^{-1}$ and incubated at $35^{\circ} \mathrm{C}$ for $3 \mathrm{~h}$. Then, when the cell density was about $1.6 \times 10^{7}$ cells ml ${ }^{-1}$, Acu was added to a final concentration of $1 \mu \mathrm{g} \mathrm{ml}^{-1}$. Incubation was continued at the same temperature for $3 \mathrm{~h}$. If at this time the RBF-like cells were immediately centrifuged, transferred into fresh medium without Acu at a cell density of $3 \times 10^{6}$ cells ml $^{-1}$ and incubated at $25^{\circ} \mathrm{C}$ (the 'recovery system'), the cells nearly stopped spherical growth and resumed their normal, that is cylindrical, growth at the tip of the spherical region along the original growth axis (see Fig. 3c), or at the tip of the cylindrical pole. These systems are summarized in Fig. 2. After recovering growth for about $3 \mathrm{~h}$, the cells began to form the cell plate.

The following experiments were performed with the mutant $c d c 10-121 \mathrm{~h}^{-}$under the conditions described above, except where noted.

\section{Ultrastructural observations of walls}

Using scanning electron microscopy no difference was observed on the cell surface, which was smooth and homogeneous between the spherical and cylindrical regions of the wall (Fig. 1).

The cell wall ultrastructure of RBF-like cells produced by Acu (Fig. $3 b, d$ ) and recovery cells released from Acu (Fig. $3 c$ ), were compared with normal cells (Fig. $3 a$ ). The spherical region was of moderate electron-density and it appeared to be loosely arranged when compared with the cylindrical region (Fig. $3 d$ ). The wall of the spherical region of the recovery cell appeared thicker than that of the cylindrical part, but the newly emerged region at the tip of the spherical part had a thinner wall than the old cylindrical wall (Fig. $3 c$ ).

\section{Morphological observations after alkali treatment}

To examine the morphology and sugar components of spherical walls formed under the incomplete inhibition of $\beta$-glucan synthesis by $\mathrm{Acu}$, cells were first treated with various concentrations of alkali. Washed cells were shaken vigorously in $0.3,0.5$ and $0.8 \mathrm{M}-\mathrm{NaOH}$ for $1 \mathrm{~min}$ and the effect of these treatments on cell morphology was observed under the phasecontrast microscope (Fig. 4). Treatment of RBF-like cells with $0 \cdot 3 \mathrm{M}-\mathrm{NaOH}$ produced a cell wall 'ghost' by lysing a part of the spherical wall (Fig. $4 a$ ), whereas similar treatment of cylindrical normal cells resulted in no obvious changes. However, lysis of normal cell walls did occur at $\mathrm{NaOH}$ concentrations higher than $0.4 \mathrm{M}$ (Fig. $4 b$ ). When the RBF-like cells were suspended in $0.5 \mathrm{M}-\mathrm{NaOH}$, the spherical regions of the ghosts were swollen like a balloon (Fig. $4 c$ ). In $0.8 \mathrm{M}-$ $\mathrm{NaOH}$, the spherical regions were dissolved but the thimble-shaped cylindrical regions remained (Fig. $4 d$ ). Under similar conditions ghosts of cylindrical cells retained their original morphology.

Electron microscopy (Fig. $4 e$ ) of a shadowed preparation of ghosts prepared in $0 \cdot 3 \mathrm{M}-\mathrm{NaOH}$ showed that the spherical region had a loosely arranged structure which was in agreement with the observations of ultra-thin sections. 


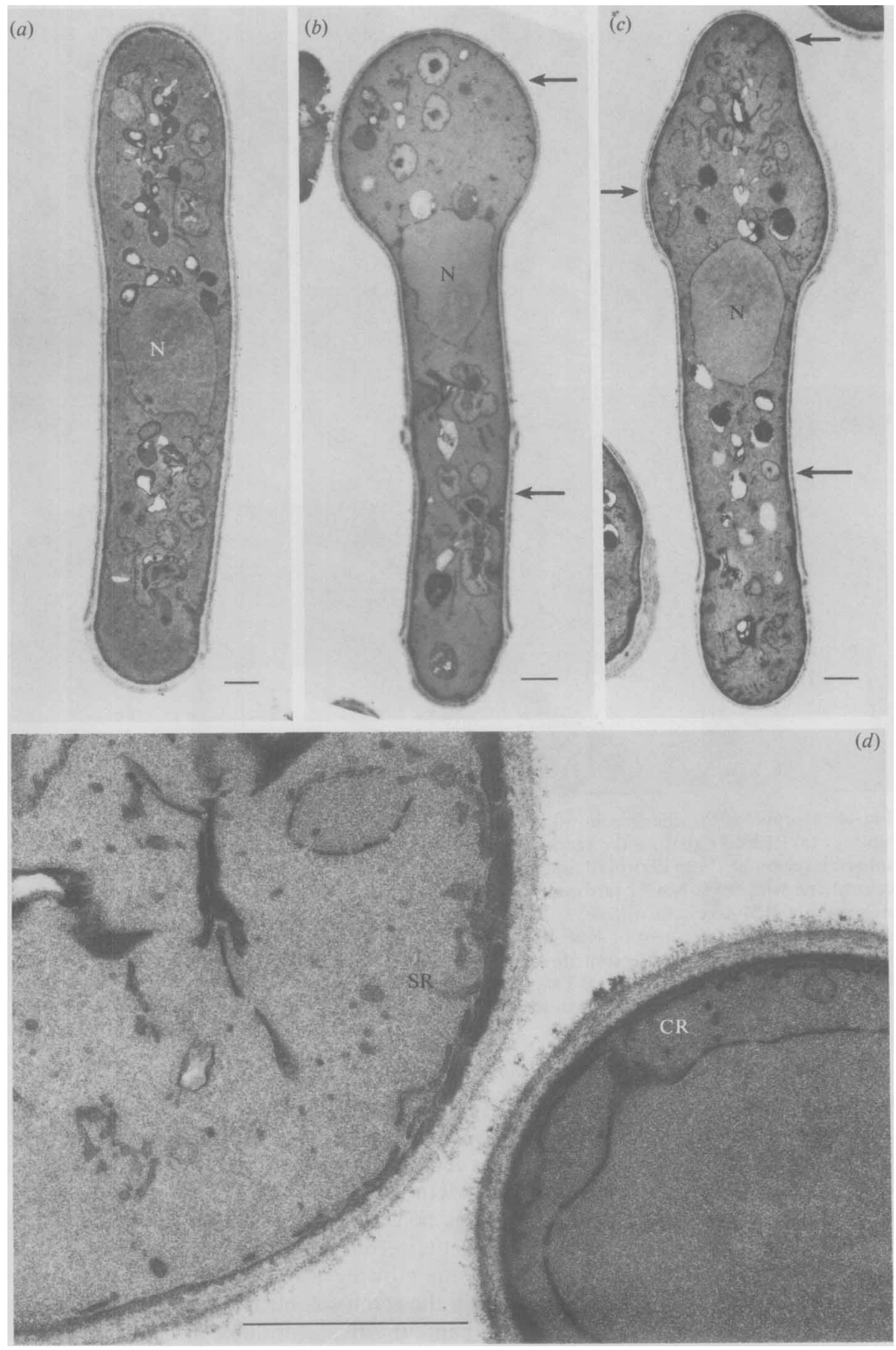

Fig. 3. Transmission electron micrographs of $(a)$ a longitudinal sectioned control cell; $(b)$ a longitudinal sectioned RBF-like cell; (c) a longitudinal sectioned recovery cell; $(d)$ cross-sections of RBF-like cells. Cells grown for $3 \mathrm{~h}$ in the absence or presence of Acu were used. Note the walls indicated by arrows. SR, spherical region; $C R$, cylindrical region; $N$, nucleus; bars, $1 \mu \mathrm{m}$. 


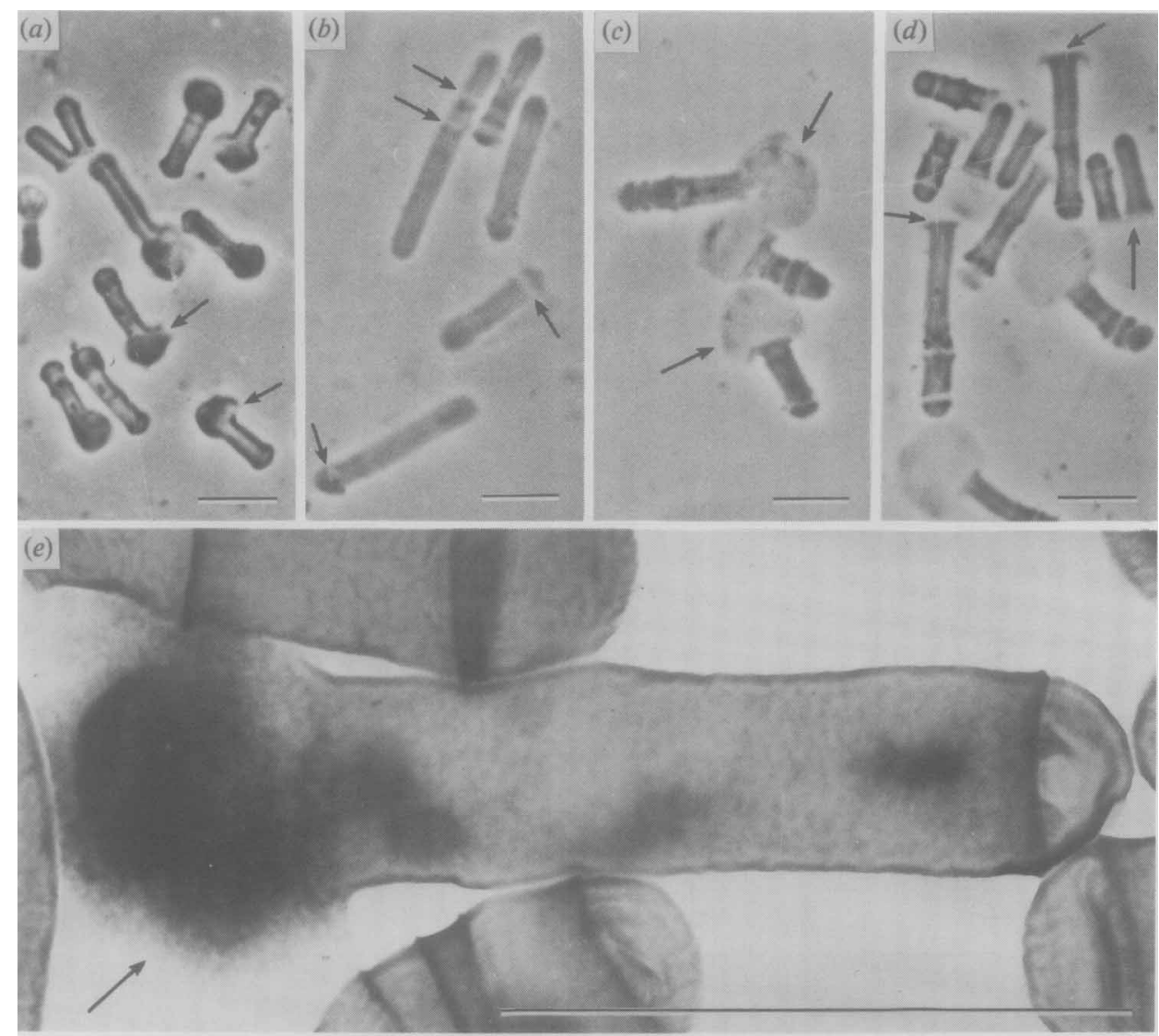

Fig. 4. Morphological changes in alkali-treated cells. $(a-d)$ Phase-contrast micrographs of their 'ghosts': (a) RBF-like ghosts after treatment of RBF-like cells with $0.3 \mathrm{M}-\mathrm{NaOH}$ (note that a part of the spherical region has been destroyed, indicated by arrows); (b) cylindrical ghosts after treatment of the control cell with $0.5 \mathrm{M}-\mathrm{NaOH}$ (arrows indicate division scars destroyed); (c) RBF-like ghosts after treatment of RBF-like cells with $0.5 \mathrm{M}-\mathrm{NaOH}$ (arrows indicate swollen spherical walls); $(d)$ thimbleshaped walls after treatment of RBF-like cells with $0.8 \mathrm{M}-\mathrm{NaOH}$ (note solubilized spherical walls, indicated by arrows). (e) Electron micrograph of shadowed preparation of RBF-like ghost after treatment of RBF-like cells with $0.3 \mathrm{M}-\mathrm{NaOH}$ (arrow indicates a loosely arranged structure of the spherical wall). Cells grown for $3 \mathrm{~h}$ in the absence or presence of Acu were used; bars, $10 \mu \mathrm{m}$.

\section{Sugar components of spherical walls}

The above observations showed that the spherical region of the cell wall was more soluble in alkali than the cylindrical region. Mannan and $\alpha$-glucan are soluble in alkali (Manners \& Meyer, 1977); therefore, in order to analyse the sugar components of the alkali-soluble fraction, the cell wall polysaccharides were fractionated (see Methods).

The changes in sugar content of the various polysaccharide fractions during the spherical growth after the addition of Acu and during the recovery growth after removing Acu were compared with polysaccharides from organisms growing as cylinders in the absence of the antibiotic (Fig. 5). The amount of total sugar in the alkali-soluble fractions from RBF-like cells was greater than in the controls. On the other hand, the alkali-insoluble fractions from RBF-like cells contained less sugar than those from the cylindrical cells (Fig. $5 a$ ). The rate of synthesis of the alkali-soluble sugar during spherical growth was greater than that of the control, while that during recovery growth paralleled the rate of the control, maintaining the difference in sugar contents.

To extend these findings, the changes in mannose and glucose content of the various 
(a)

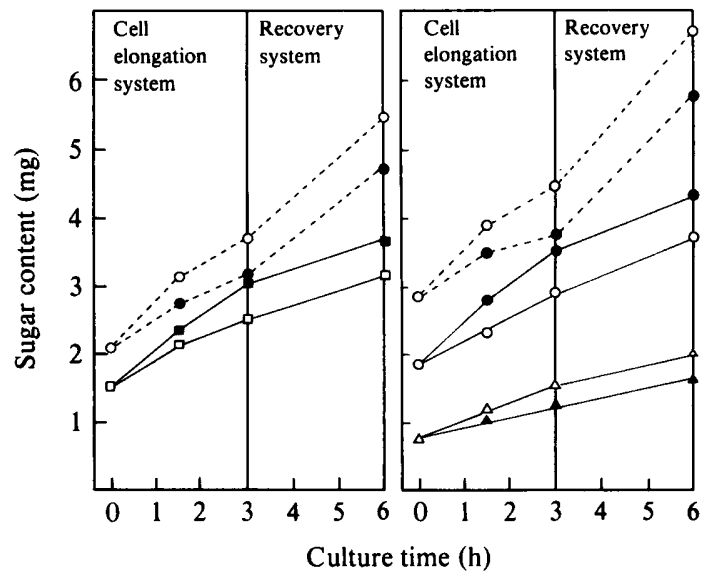

Fig. 5. Variations of sugar contents of cells fractionated with alkali through spherical growth and recovery growth. (a) Determination by the anthrone method, calculated as glucose equivalent; $(b)$ determination by the $\mathrm{H}_{2} \mathrm{SO}_{4}$ /carbazole method. In alkali-insoluble fractions: $\mathrm{O}^{--}-\mathrm{O}$, glucose of control cells; -- , glucose of RBF-like or recovery cells. In alkali-soluble fractions; $\square$, total sugar of control cells; $\square$, total sugars of RBF-like or recovery cells; $O$, glucose of control cells; $\bigcirc$, glucose of RBF-like or recovery cells; $\Delta$, mannose of control cells; $\boldsymbol{\Delta}$, mannose of RBF-like or recovery cells. These sugar patterns were reproduced from three sets of measurements. Total cell number per sample used was $4.8 \times 10^{8}$ cells.

polysaccharides were studied (Fig. $5 b$ ). Gas-liquid chromatography showed that the alkalisoluble fraction contained glucose, mannose and galactose, while the alkali-insoluble fraction contained glucose and galactose. The mannose content in the alkali-soluble fraction of the RBFlike cells was less than that of the cylindrical cells whereas the opposite was found for glucose. In the alkali-insoluble fractions only glucose had the same result as shown in Fig. 5(a).

These findings suggest that the carbohydrate syntheses of the spherical wall were reduced in $\beta$-glucan and mannan but enhanced in $\alpha$-glucan, and that $\alpha$-glucan was the main component of the spherical wall.

\section{Morphological observations of enzymic digestions of wall polysaccharides}

To confirm the suggestion described above, enzymic digestions of the cell wall were attempted. If the spherical wall was composed mainly of $\alpha$-glucan, it would be lysed by $\alpha$ glucanase but not by $\beta$-glucanase. In this experiment, Novozym 234 and Zymolyase 60000 were used as a $(1 \rightarrow 3)$ - $\alpha$-glucanase and a $(1 \rightarrow 3)$ - $\beta$-glucanase, respectively (Dickinson \& Isenberg, 1982).

The wall of the spherical region was digested by Novozym 234 in $10 \mathrm{~min}$ but that of the cylindrical region was not (Figs 6 and 7). Zymolyase 60000, on the other hand, digested the cylindrical but not the spherical wall, though the digestion required $90 \mathrm{~min}$. The cells with normal shapes were not digested by Novozym 234 under the mild conditions chosen, but the wall of the rounded end, which was the primary pole (according to Johnson, 1965) with newly synthesized wall, was digested when the cells were treated either with an increased concentration of enzyme or for a longer time (Fig. $7 b$ ). This resulted in the cytoplasm being extruded leaving an undigested wall skeleton shaped like a thimble.

In the Novozym 234 digestion, cytoplasm was extruded through the undigested wall (Fig. 7) whereas in the Zymolyase 60000 digestion it was not (Fig. $6 b$ ). The cytoplasm treated with Novozym 234 had no vestige of the wall (Fig. $6 a$ ) whereas that treated with Zymolyase 60000 retained the thin innermost layer of the wall (Fig. $6 b$ ). Moreover, the naked cytoplasm obtained by the treatment with Novozym 234 was destroyed by $\mathrm{KMnO}_{4}$ postfixation, whereas that treated with Zymolyase 60000 was not (Methods). From the difference between the responses of fixed cells to digestion with Novozym 234 and Zymolyase 60000, we concluded that Novozym 


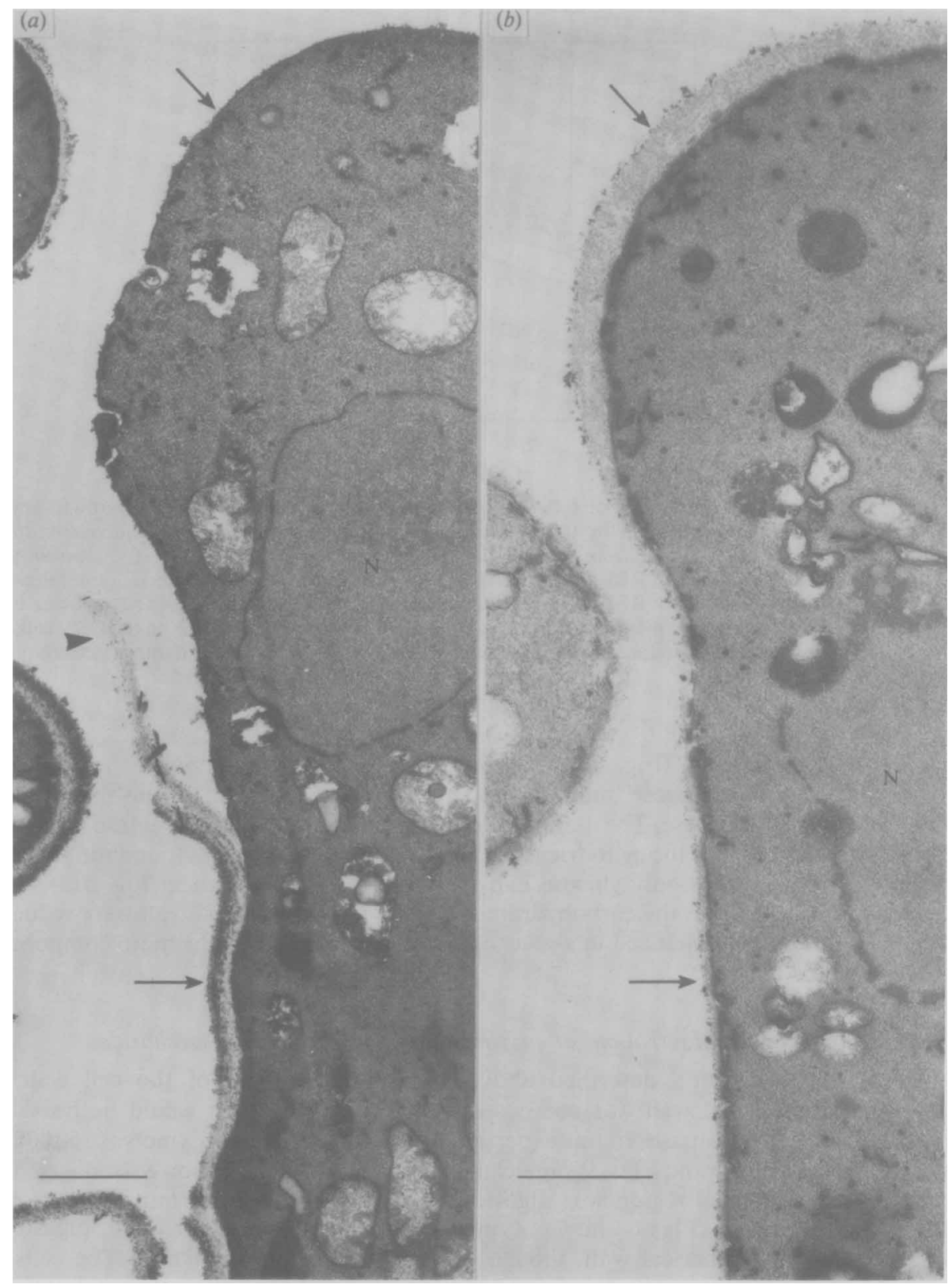

Fig. 6. Effects of $\alpha$ - and $\beta$-glucanases on RBF-like cell walls. (a) Effect of Novozym 234 [a $(1 \rightarrow 3)-\alpha-$ glucanase]; note that the spherical wall has been digested but the cylindrical wall has remained (arrows) and that the half-digested wall has peeled from the cytoplasm, as indicated by the arrowhead. (b) Effect of Zymolyase 60000 [a $(1 \rightarrow 3)-\beta$-glucanase]; note that the cylindrical wall has been digested but the spherical wall has remained (arrows). Note that in $(b)$ the innermost layer of the wall on the cytoplasmic membrane has remained, as indicated by the arrow at the region of the cylinder, while in $(a)$ it has not, as indicated by the arrow at the region of the sphere; bars, $1 \mu \mathrm{m}$.

234 acted on the innermost layer of the cylindrical cell wall which was digested, and then the cytoplasm was extruded from the thimble-shaped cell wall (Fig. 7). This hypothesis is compatible with the differences in fixation by $\mathrm{KMnO}_{4}$ between glutaraldehyde-fixed cells treated with Novozym 234 and with Zymolyase 60000. 


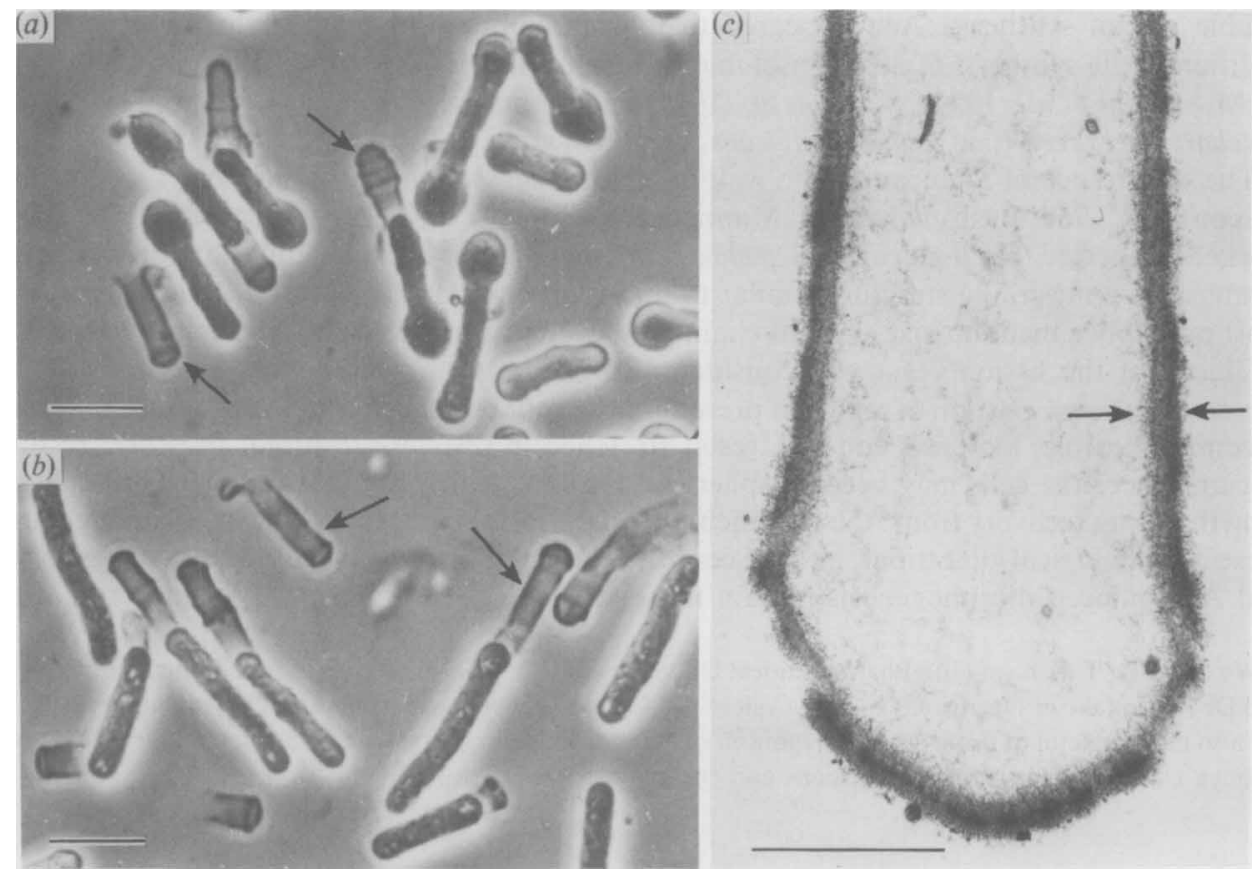

Fig. 7. $(a, b)$ Phase-contrast micrographs of thimble-shaped cell walls (arrows) remaining after the extrusion of cytoplasm following digestion with Novozym 234: (a) after the treatment of RBF-like cells with the enzyme for $10 \mathrm{~min} ;(b)$ after the treatment of control cells for $40 \mathrm{~min}$. (c) Electron micrograph of a single, thin-sectioned, thimble-shaped cell wall. Note that the cell wall structure is nearly intact (arrows). $(a, b)$ Bars, $10 \mu \mathrm{m}$; (c) bar, $1 \mu \mathrm{m}$.

\section{DISCUSSION}

Cells of $S$. pombe are normally cylindrical in shape with rounded ends but they assumed a RBF-like shape when their growth was incompletely inhibited by Acu, an inhibitor of $\beta$-glucan synthesis (Mizoguchi et al., 1977; Yamaguchi et al., 1982). The cylindrical cell of $S$. pombe grows exclusively but not equally at the poles, without detectable change in the cell radius (May, 1962; Johnson, 1965; Johnson et al., 1979; Streiblová \& Wolf, 1972; Streiblová, 1981). Streiblová \& Wolf (1972) reported that during the first half of the cell cycle the cells grow unipolarly at the primary end, which is located opposite the pole of the previous division, and that during the second half of the cell cycle the cells grow bipolarly. H. Miyata (personal communication) had also observed similar patterns with oversized cell growth produced by hydroxyurea treatment.

The RBF-like morphological alteration formed in the presence of Acu was accompanied by an increase in wall polysaccharides. Since the RBF-like cells always have a division scar at the end of the cylindrical region and the spherical region never has division scars (Fig. 1), we can conclude that under the experimental conditions used in this work the cells grew only unipolarly. Thus the spherical region represents the newly synthesized wall and the cylindrical region is older wall.

Previously (Miyata et al., 1980), we demonstrated that the wall of morphologically altered cells stained with a fluorescent brightener more extensively in the spherical region than in the cylindrical region. This observation implied change in the chemical composition and/or the microfibril orientation of the cell wall in the spherical region. The basal wall structure of bakers' yeast which is responsible for maintaining the shape and rigidity of the cell consists of $\beta$-glucan (Manners et al., 1973). The wall of $S$. pombe also contains $\beta$-glucan as the main component but $\alpha$ glucan is also present, unlike the walls of other ascomycetous yeasts (Bacon et al., 1968; Bush $e t$ al., 1974; Manners \& Meyer, 1977). In this study carbohydrate analyses showed that the RBFlike cells decreased in alkali-insoluble glucan and mannan syntheses but increased in alkali- 
soluble glucan synthesis. Acu appeared to inhibit synthesis of mannan to some extent, in addition to the synthesis of alkali-insoluble $\beta$-glucan. This finding is in agreement with reports by Mizoguchi et al. (1977), Singh et al. (1979) and Yamaguchi et al. (1982) who worked with Saccharomyces cerevisiae, Candida albicans AY F-598 and C. albicans MTU 12077, respectively.

The occurrence of $\alpha$-glucan in the wall of a Schizosaccharomyces sp. has been investigated (Bacon et al., 1968; Bush et al., 1974; Manners \& Meyer, 1977; Kreger \& Kopecká, 1978). These workers suggested that $\beta$-glucan of $S$. pombe was a more or less branched fibrillar polysaccharide arranged in a mesh-like structure similar to that found in bakers' yeast, but that $\alpha$-glucan was most probably a medium-size straight chain polysaccharide of amorphous structure in the wall. $\beta$-Glucan of the fission yeast was considered to be the principal support of cell shape. An increase in the proportion of $\alpha$-glucan present in the wall polysaccharides may result in the wall becoming flexible, loosened and as a result stretched in response to turgor pressure. In these circumstances the cells may become spherical. However, the problems of polarity of cell wall growth during recovery from Acu treatment, the nature of the internal changes occurring during these morphological alterations, and the coordinate regulation of $\beta$-and $\alpha$-glucans during normal and Acu-induced morphogenesis remain to be studied.

We thank Dr T. Kiho of Gifu Pharmaceutical University for technical assistance in gas chromatographic work and Dr K. Onitake of Nagoya University College of Medical Technology for scanning electron microscopy. We are also most grateful to Professor B. F. Johnson of National Research Council of Canada and Dr H. Miyata of Nagoya University for helpful discussions and encouragements.

\section{REFERENCES}

BARTNICKI-GarCIA, S. \& MCMURROUGH, I. (1971). Biochemistry of morphogenesis in yeasts. In The Yeasts, vol. 2, pp. 441-491. Edited by A. H. Rose \& J. S. Harrison. New York \& London: Academic Press.

Bacon, J. S., Jones, D., Farmer, V. C. \& Webley, D. M. (1968). The occurrence of $\alpha-(1 \rightarrow 3)$-glucan in Cryptococcus, Schizosaccharomyces and Polyporus species, and its hydrolysis by a Streptomyces culture filtrate lysing cell walls of Cryptococcus. Biochimica t biophysica acta 158, 313-315.

Bush, D. A., Horisberger, M., Horman, I. \& WuRSCH, P. (1974). The wall structure of Schizosaccharomyces pombe. Journal of General Microbiology 81, 199-206.

Cabib, E. \& Roberts, R. (1982). Synthesis of the yeast cell wall and its regulation. Annual Review of Biochemistry 51, 763-793.

DiCKINSON, D. P. \& ISENBERG, I. (1982). Preparation of spheroplasts of Schizosaccharomyces pombe. Journal of General Microbiology 128, 651-654.

Herbert, D., Phipps, P. J. \& Strange, R. E. (1971). Chemical analysis of microbial cells. Methods in Microbiology 5B, 209-344.

HiRata, A. \& Tanaka, K. (1982). Nuclear behavior during conjugation and meiosis in the fission yeast Schizosaccharomyces pombe. Journal of General and Applied Microbiology 28, 263-274.

JoHNSON, B. F. (1965). Autoradiographic analysis of regional cell wall growth of yeasts. Schizosaccharomyces pombe. Experimental Cell Research 39, 613624.

Johnson, B. F., Calleja, G. B., Boisclair, I. \& Yoo, B. Y. (1979). Cell division in yeasts. III. The biased, asymmetric location of the septum in the fission yeast cell, Schizosaccharomyces pombe. Experimental Cell Research 123, 253-259.
KREGER, D. R. \& KopeCKÁ, M. (1978). Nature of the nets produced by protoplasts of Schizosaccharomyces pombe during the first stage of wall regeneration in liquid media. Journal of General Microbiology 108, 269-274.

ManNers, D. J. \& Meyer, M. T. (1977). The molecular structures of some glucans from the cell walls of Schizosaccharomyces pombe. Carbohydrate Research 57, 189-203.

Manners, D. J., Masson, A. J. \& Patterson, J. C. (1973). The structure of a $\beta$-( $1 \rightarrow 3)$-D-glucan from yeast cell walls. Biochemical Journal 135, 19-30.

MAY, J. W. (1962). Sites of cell wall extension demonstrated by the use of fiuorescent antibody. Experimental Cell Research 27, 170-172.

McMurrough, I. \& Rose, A. H. (1967). Effect of growth rate and substrate limitation on the composition and structure of the cell wall of Saccharomyces cerevisiae. Biochemical Journal 105, 189-203.

Mitchison, J. M. (1970). Physiological and cytological methods for Schizosaccharomyces pombe. Methods in Cell Physiology 4, 131-165.

Miyata, M. \& Miyata, H. (1978). Relationship between extracellular enzymes and cell growth during the cell cycle of the fission yeast Schizosaccharomyces pombe: acid phosphatase. Journal of Bacteriology 136, 558-564.

Miyata, M., Kitamura, J. \& Miyata, H. (1980). Lysis of growing fission-yeast cells induced by aculeacin A, a new antifungal antibiotic. Archives of Microbiology 127, 11-16.

Mizoguchi, J., Saito, T., Mizuno, K. \& Hayano, K. (1977). On the mode of action of a new antifungal antibiotic, aculeacin A: inhibition of cell wall synthesis in Saccharomyces cerevisiae. Journal of Antibiotics 30, 308-313.

NeČAS, O. \& SvoBODA, A. (1980). Morphogenesis in 
protoplasts. In Yeast Cell Envelopes: Biochemistry, Biophysics and Ultrastructure vol. II, pp. 105-127. Edited by W. N. Arnold. Boca Raton, Florida : CRC Press.

NorthCote, D. M. \& HoRne, R. W. (1952). The chemical composition and structure of yeast cell wall. Biochemical Journal 51, 232-236.

Nurse, P., ThuriauX, P. \& Nasmyth, K. (1976). Genetic control of the cell division cycle in the fission yeast Schizosaccharomyces pombe. Molecular and General Genetics 146, 167-178.

SinGH, K., SuN, S. \& VÉZiNA, C. (1979). Rapamycin (AY-22, 989), a new antifungal antibiotic IV. Mechanism of action. Journal of Antibiotics 32, 630 645.

SLONECKER, J. H. (1972). Gas-liquid chromatography of alditol acetates. Methods in Carbohydrate Chemis$\operatorname{try}$ 6, 20-24.

SPURR, A. R. (1969). A low-viscosity epoxy resin embedding medium for electron microscopy. Journal of Ultrastructural Research 26, 31-43.

Streiblová, E. (1981). Fission. In Yeast Cell Envelopes: Biochemistry, Biophysics and Ultrastructure vol. II, pp. 79-92. Edited by W. N. Arnold. Boca Raton, Florida: CRC Press.

Streiblová, E. \& Wolf, A. (1972). Cell wall growth during the cell cycle of Schizosaccharomyces pombe. Zeitschrift für allgemeine Mikrobiologie 12, 673-684.

Yamaguchi, H., HiRatani, T., IWATA, K. \& Yamamoto, Y. (1982). Studies on the mechanism of antifungal action of aculeacin A. Journal of Antibiotics 35, 210-219. 